\title{
FILOSOFIS KOMUNIKASI QAULAN SYAKILA
}

\section{Fahriansyah}

\section{UIN Antasari Banjarmasin}

\begin{abstract}
The principles of comunication in the Qur'an are interesting to examine, even the comunications thinkers have found there are six principles of comunication in al qur'an such as qawlan sadidan, qawlan balighan, qawlan maysura, qawlan layyinan, qawlan kariman and qawlan ma'rufan, but the opinion can be added again one principle that is qawlan tsaqila principle that is a weighted communication, then what and how qawlan tsaqila?, this paper will explain briefly iti is in addition to the six principles of comunication in al Qur'an put forward by the communications leaders muslim Indonesia.
\end{abstract}

Keywords: Al Qur'an; principless of communication of the ability of blessing; qawlan tsaqiila.

\section{Pendahuluan}

Jalaluddin Rakhmat seorang cendikiawan muslim Indonesia dalam bukunya "Islam Aktual" mengemukakan prinsip-prinsip komunikasi dalam Al Qur'an yang terdiri dari enam Prinsip komunikasi yakni : Qawlan Sadidan (QS 4;9), Qawlan Balighan (QS 4:63) ,Qawlan Maysuran (QS 17:28), qawlan layyinan (QS 20:44), qawlan kariman (QS 17;23), qawlan ma'rufan (QS 4:5) ${ }^{27}$, yang kemudian pendapat ini dikutip oleh HM. Tata Taufik dalam bukunya "Etika Komunikasi Islam"28, kemudian dikutip pula oleh Ujang Saefullah dalam bukunya "Kapita Selekta Komunikasi Pendekatan

27 Jalaluddin Rakhmat, Islam Aktual, Refleksi Seorang Cendikiawan Muslim, Mizan, Bandung, 1991,h.77.

28 Tata Taufik,HM, Etika Komunikasi Islam,Pustaka Setia, Bandung, 2012, 118-119. 
Budaya dan Agama"29 serta Achmad Mubarok dalam bukunya "Psikologi Dakwah Membangun Cara Berpikir dan Merasa."30

Akan tetapi jika dicermati lagi pemikiran tersebut ada satu prinsip komunikasi dalam al Qur'an yang menggunakan kata "qaulan" yang belum dibahas dalam pemikiran Jalaluddin Rakhmat tersebut yaitu yang tercantum dalam surat al Muzammil ayat 5:

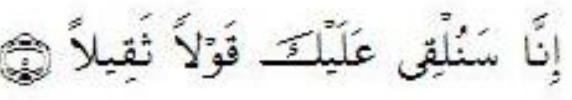

"Sesungguhnya Kami akan menurunkan kapadamu Perkataan yang berat."

Lalu bagaimanakah sebenarnya prinsif komunikasi "Qaulan Syakila" tersebut, apakah ada padanannya dengan perkembangan ilmu komunikasi yang berkembang sampai sekarang ini?.

\section{Pembahasan}

\section{Kemampuan Berbicara (Qaulan)}

Tidak dapat disangkal bahwa berbicara mempunyai peranan sosial yang sangat penting dalam kehidupan manusia. Berbicara merupakan alat komunikasi tatap muka yang sangat vital. Kemampuan berbicara seseorang turut menentukan kesuksesan kariernya. Disatu pihak berbicara merupakan suatu daya pemersatu yang ampuh yang cenderung mempersatukan kelompok-kelompok sosial. Dipihak lain, berbicara dapat pula bertindak sebagai suatu daya pemecah belah, yang cenderung mempertajam perbedaan-perbedaan antara kelompok-kelompok sosial. Demikianlah berbicara dapat membuahkan kutub konstruktif maupun kutub destruktif. Dengan

29 Ujang Saefullah, Kapita Selekta Komunikasi Pendekatan Budaya dan Agama, Simbiosa Rekatama Media, Bandung, 2013, h.69-100.

30 Achmad Mubarok, Psikologi Dakwah Membangun Cara Berpikir dan Merasa, Madani, Malang, 2014,h.205-208. 
perkataan lain, berbicara dapat mendatangkan kedamaian, menumbuhkan cinta dan dapat pula menimbulkan perang, menumbuhkan benci, tergantung kepada kondisi dan situasi. ${ }^{31}$

Kemampuan berbicara sangat erat kaitannya dengan keberadaan bahasa lisan ${ }^{32}$ saking pentingnya kajian untuk mengasah kemampuan berbicara, manusia mengembangkan berbagai disiplin ilmu seperti Retorika, Psikolinguistik, Sosiolinguistik, Metode linguistik bahkan ada perguruan tinggi yang khusus mengkaji dan mempelajari bidang linguistik, bahkan dalam ilmu psikologi salah satu keunggulan manusia dengan makhluk yang lainnya adalah faktor kemampuannya dalam berbicara dengan berbagai variasinya, bahkan dengan kemampuan manusia berbicara atau berbahasa lisan mampu membentuk berbagai macam peradaban pada kehidupan manusia. ${ }^{33}$

Dori Wuwur Hendrikus menyatakan bahwa berbicara atau berbahasa lisan bagi manusia akan melibatkan 2 aspek penting yakni: Aspek Isi dan Relasi serta aspek Perasaan. ${ }^{34}$ Untuk mensukseskan hal tersebut diperlukan 4 (empat) ketrampilan yang harus dikuasai yakni: (1) Ketrampilan Sosial (social skill), (2) Ketrampilan Semantik (semantic skill), (3) Ketrampilan Fonetik (phonetic skill), (4) Ketrampilan vocal (vocal skill $)^{35}$.

Bakat kemampuan bicara (bahasa Lisan) manusia semakin maksimal jika melibatkan 5 potensi pengembangan daya bakat

${ }^{31}$ Henry Guntur Tarigan, Berbicara Sebagai Suatu Ketrampilan Berbahasa, Angkasa, Bandung,t,1993,h.iii.

32 Zulkifli Musabba, Terampil Berbicara Teori dan Pedoman Penerapannya, CV Aswaja Pressindo, Yogyakarta. 2012, h.8.

33 Lihat Nina Winangsih Syam, Komunikasi Peradaban, PT Remadja Rosdakarya, Bandung, 2014.

34 Dori Wuwur Henddrikus, Seni Berbicara, Ledalero, Maumere, 2014, 18-22.

${ }^{35}$ Henry Guntur Tarigan, Op.Cit,h.19. 
kemampuan manusia yaitu: Ruh, Rasa-Hati-Aqal dan Nafsu'36, Ruh menurut al Ghazali merupakan lathifah (sesuatu yang halus) yang bersifat ruhani, ia dapat berpikir,mengingat, mengetahui ${ }^{37}$, Rasa-HatiAqal adalah sebagai penimbang nilai-nilai kebaikan, sedangkan nafsu adalah daya dorong manusia untuk selalu eksis dalam kehidupan ${ }^{38}$

Al Ghazali dalam karyanya yang terkenal Ihya Ulumuddien menulis secara khusus tentang Bahaya Lisan;" Lisan dapat menyelamatkan manusia dan kadang pula dapat mencelakakan.Lisan dapat mengantar manusia pada hadirat Allah, namun bisa pula menghalanginya, bahkan mengantarkan seseorang kejurang neraka ${ }^{39}$, menghindari hal-hal yang negatif dalam bahasa lisan seperti: (1) Jangan berbicara tentang sesuatu yang tak penting, (2) Jangan berbicara berlebih-lebihan, (3) Jangan berbicara tentang sesuatu yang batil dengan berlebihan, (4) Hindari peredebatan yang tidak menguntungkan, (5) Hindari pertengkaran, (6) Hindari kefasihan bicara yang dibuat-buat, (7) Hindari perbuatan melaknat, (8) berlebihan bersenda gurau, (9) mengejek dan mentertawakan, (10) Membuka aib orang lain, (11) janji dusta, (12) Bohong dan sumpah palsu, (13) mengumpat, (14) Mengadu domba ${ }^{40}$ sangatlah baik oleh seorang muslim agar dalam selamat dalam kehidupannya.

\footnotetext{
${ }^{36}$ Lihat Ki Moenadi MS, Pengembangan Daya Bakat Kemampuan Manusia, Tanpa Penerbit, T.Th,

37 Abdul Mujib,et.al, Nuansa-nuansa Psikologi Islam, PT.RajaGrafindo Persada,Jakarta,2002,h.42.

38 Sukanto, Nafsiologi Refleksi Analisis Tentang Diri dan Tingkah Laku Manusia, Risalah Gusti,1995 banyak membahas tentang sisi positif dari Nafsu sebagai potensi manusia dan berbagai cara pertahanan agar nafsu tidak menjurus kepada hal-hal negatif yang bisa merugikan manusia.

39 Imam Al Ghazali, Ringkasan Ihya 'Ulumudin, Penyuting Abu Fajar Al Qalami, Gitamedia Press, Surabaya, 2003,h.207.

40 Ibid.h.207-220.
} 


\section{Filosofi Qaulan Syakila}

Meneliti tentang apa sebenarnya prinsip komunikasi "Qaulan Syakila" maka sebaiknya melihat pada surat al Muzammil ayat 1-5:

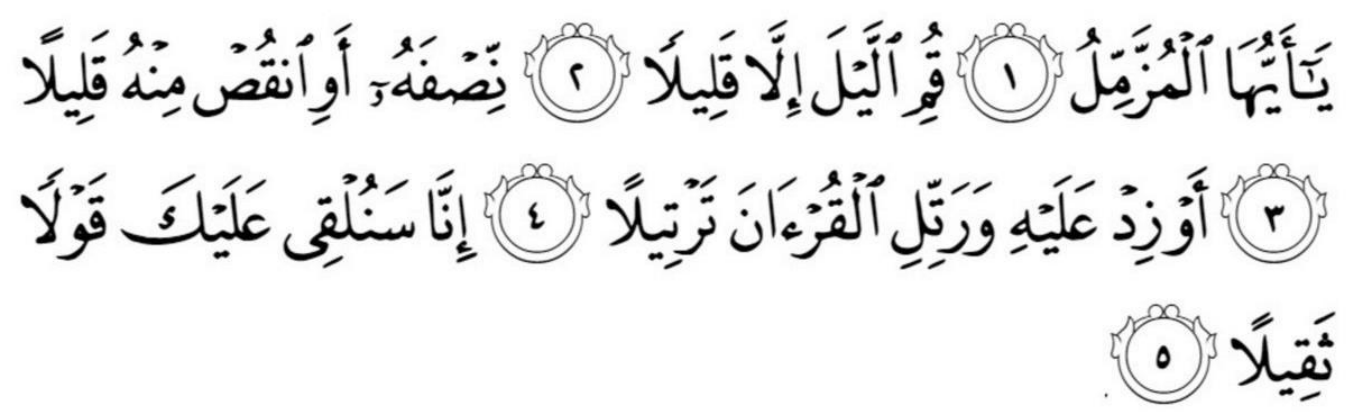

1. Hai orang yang berselimut (Muhammad),

2. Bangunlah (untuk sembahyang) di malam hari, kecuali sedikit (daripadanya),

3. (Yaitu) seperduanya atau kurangilah dari seperdua itu sedikit.

4. Atau lebih dari seperdua itu. dan bacalah Al Quran itu dengan perlahan-lahan.

5. Sesungguhnya Kami akan menurunkan kapadamu Perkataan yang berat.

Mayoritas para mufasir menafsirkan kata "Qaulan Syakiila" (perkataan yang berat itu adalah Al Qur'an ${ }^{41}$, lalu mengapa al Qur'an dikategorikan sebagai lisan yang berbobot/ berkualitas, hal ini disebabkan secara umum dinyatakan dalam al Qur'an surat Al Baqarah ayat 185 berisikan pesan-pesan yang bersifat: Huda (petunjuk), Bayyinat (penjelasan tentang petunjuk) dan Furqan

${ }^{41}$ Misalnya Tafsir Jalalain juga menafsirkan "qaulan syakiila" dengan perkataan atau bacaan Al Qur'an (yang berat) yang hebat, M Quraish Shihab menjelaskan sesungguhnya Kami akan memberikan kepadamu Wahai Rasul al Qur'an yang mengandung Perintah, Larangan dan tugas-tugas yang berat. 
(pembeda antara yang hak dan batil) ${ }^{42}$ yang terwujud dalam perintah dan larangan ${ }^{43}$,

Imam Baidhawi, A-Suyuthi menyatakan ayat Al Baqarah: 185 menyatakan bahwa Al Qur'an diturunkan oleh Allah swt berfungsi sebagai hudan, bayyinat dan furqan. Maknanya. Al Qur'an adalah petunjuk bagi manusia, memberikan penjelasan tentang mana yang halal dan mana yang haram juga tentang berbagai hudud dan hukumhukum Allah swt, serta pembeda mana yang haq dan mana yang bathil. 44

Persoalan tersebut oleh ulama dikategorikan sebagai hukum taklifi 45 adalah berkenaan dalam persoalan nilai suatu perbuatan, yang dalam Filsafat banyak dibahas dalam dunia Filsafat Nilai ${ }^{46}$, membahas tentang baik-buruk atau disukai atau tidak diinginkannya suatu perbuatan. Bila perbuatan baik-buruk sesuai dengan kenyataan

42 QS Al Baqarah : 185 : " Bulan Ramadhan, bulan yang di dalamnya diturunkan (permulaan) Al Quran sebagai petunjuk bagi manusia dan penjelasan-penjelasan mengenai petunjuk itu dan pembeda (antara yang hak dan yang bathil)"

43 Contoh perintah "Sesungguhnya Allah menyuruh kamu menyampaikan amanat kepada yang berhak menerimanya (QS an Nisa:58), dan Larangan :" Sesungguhnya Allah melarang kamu menjadikan sebagai kawanmu orang-orang yang memerangi kamu karena agama dan mengusir kamu dari negerimu dan membantu (oranglain) untuk mengusirmu (QS al-Mumtahanah: 9).

${ }^{44}$ Al Ustadz Adam Cholil, Dahsyatnya Al Qur'an, Al Qur'anul Karim menjadi petunjuk dan solusi Bagi Umat Manusia dalam mengarungi Samudera kehidupan, AMP Pres, Jakarta, 2014,h.68.

45 Untuk mengetahui lebih jauh tentang Filsafat Nilai lihat buku Muhammad Alfan berjudul: “Pengantar Filsafat Nilai”, Pustaka Setia, Bandung, 2013.

46 Hukum Taklifi menurut ahli ushul fiqh adalah ketentuan-ketentuan Allah yang berhubungan langsung dengan perbuatan orang yang mukallaf, baik itu perintah atau laranganyang diwujudkan dalam 5 peristilahan: (1) Wajib : suatu perbuatan yang apabila dikerjakan mendapatkan pahala dan apabila ditinggalkan mendapatkan dosa,(2) Sunah: suatu perbuatan yang apabila dikerjakan mendapatkan pahala dan apabila ditinggalkan tidak berdosa, (3) Haram: suatu perbuatan yang apabila ditinggalkan mendapatkan pahala dan apabila dikerjakan mendapatkan dosa, (4) Makruh: suatu perbuatan apabila ditinggakan mendapatkan pahala dan jika dikerjakan tidaklah berdosa, dan (5) Mubah: suatu perbuatan yang apabila dikerjakan atau ditinggalkan sama saja tidak mendapat pahala atau dosa. 
(kebenaran) maka masuklah pada persoalan etika/akhlaq seseorang, jika menyangkut sesuatu yang disukai dan tidak sukai akan memasuki wilayah estetika, melihat hal ini maka suatu perkataan (qaul) akan berbobot atau bermutu jika memperhatikan persoalan etika dan estetika, ${ }^{47}$ keduanya diwujudkan dalam etos bertutur dan estitika bicara, etos bertutur/berbicara dipelajari dalam ilmu etika/akhlaq dan estetika bicara dipelajari dalam retorika. 48

Ethos komunikasi menurut Aristoteles terdiri dari : pikiran baik (good sense), akhlak yang baik (good moral character) dan maksud yang baik (good will) ${ }^{49}$, Estetika cabang filsafat yang menelaah dan membahas tentang seni dan keindahan serta tanggapan manusia terhadapnya atau sebuah filosofi yang mempelajari nilai kepekaan terhadap penilaian rasa, pada perkembangannya pengunaan estetika melahirkan terminologi estetis yang berarti indah dan berkenaan dengan keindahan, keindahan adalah nilai yang diberikan pada sesuatu yang dianggap mengandung unsur seni.Karenanya berbicara atau pembicaraan seseorang akan masuk dalam perkataan yang bermutu atau berbobot jika memiliki atau memenuhi kriteria etika dan estetika yang baik. 50

47 Wahyu Wibowo dalam bukunya yang berjudul : Konsep Tindak Tutur Komunikasi, Bumi Aksara, Jakarta, 2016.

48 Dalam hadist yang diriwayatkan oleh Al Bukhari hadits no 10 berbunyi: Seorang muslim adalah orang yang lidah dan tangannya tidak menyakiti muslim lainnya.....", hadits no 11 berbunyi : .... Ya Rasulullah siapa muslim yang terbaik ?, Beliau menjawab : Muslim yang lidah dan tangannya tidak menyakiti muslim lainnya".

49 Jalaluddin Rakhmad, Psikologi Komunikasi, Remadja Karya, Bandung, 1989,h.290.

50 M.Najmi Fathoni banyak memberikan contoh-contoh cara berkomunikasi yang dilakukan oleh nabi Muhammad saw sehingga diberi gelar Al Amien dalam bukunya yang berjudul : Strategi Komunikasi Model Sang Nabi, mengupas kecerdasan komunikasi Nabi Muhammad saw, PT Elex Media Komputindo, Jakarta, 2018. 
Dalam dunia komunikasi modern dikenal adanya istilah "Neuro Linguistik Programming" (NLP) ${ }^{51}$ yang mengkaji dan menyimpulkan bahwa seseorang berbahasa atau berbicara dipengaruhi oleh sistem syaraf otak dan seluruh tubuh manusia, jika sistem syaraf otak dan tubuh manusia terganggu maka akan mempengaruhi pada kemampuan berbicara/berbahasa orang tersebut, sebaliknya jika sistem syaraf otak dan tubuh manusia baik maka kemampuan berbicara/berbahasa juga baik.

Bahwa berbicara adalah respon seseorang (konseptual) terhadap suatu realitas yang ada pada tubuh seseorang (sistem neurologi) dan mental, artinya apa yang ada dalam pikiran seseorang sesungguhnya hanyalah persepsinya akan suatu realitas atau peristiwa yang masuk melalui panca indera (kepekaan inderawi) dan kemudian diubah menjadi kode bahasa dalam sistem neuro manusia. Mengintroduksi konsep komunikasi "Neuro Linguistik Programming" (NLP) maka perkataan yang berbobot yang diwujudkan dalam etika dan estetika berbicara hanya akan bisa terjadi jika komunikatornya adalah orangorang secara sistem neurolognya baik, yakni manusia-manusia yang memiliki ketenangan jiwa akan mampu melahirkan ucapan-ucapan yang berbobot/ berkualitas, bahwa orang yang sudah mendapatkan ketenangan jiwa akan mampu membentuk etika dan estetika dalam setiap pembicaraannya.

Nabi Muhammad saw sebelum diangkat menjadi Rasul diberi gelar oleh masyarakat dengan sebutan "Al-Amien" (yang dipercaya), gelar ini secara umum mengarah kepada bobot/ kualitas apa yang dikatakan (dibicarakan) oleh Muhammad saw yang selalu jujur, baik

51 Untuk lebih lengkapnya lihat buku karya Annie Sailendra berjudul " Neuro Linguistic Programming (NLP) dari konsep hingga teknik, Solusi Distribusi, Yogyakarta, 2014. 
dalam ucapan maupun tindakan, sehingga beliau memiliki karakter ${ }^{52}$ dan perilaku tersebut menjadi contoh atau rujukan bagi masyarakat ${ }^{53}$

Dalam Surat Al Muzammil ayat 5 dinyatakan: "Sesungguhnya Kami akan menurunkan kepadamu Perkataan yang berat" dikaitkan dengan kegiatan shalat malam dan membaca al-Qur'an secara tartil (perlahan-lahan), "Suatu perkataan dipandang berbobot apabila mampu memberikan jalan keluar dari problematik kehidupan. Dengan shalat malam (tahajjud), kita akan memiliki kekuatan spiritual yang terus mengalir.Kedekatan dengan Allah menjadikan kita memiliki kontak langsung denganNya sehingga Allah SWT menurunkan kemampuan yang tidak dimiliki oleh orang lain; dalam bentuk perkataan yang berbobot." 54

Kamaruddin Hidayat menulis: "Jika shalat dihayati dan dilaksanakan dengan serius, terlebih shalat malam, maka seseorang akan terbebas dari jeratan obyek-obyek kecintaan dunia yang serba sementara, karena dengan shalat kesadaran dan orientasi hidup seseorang menjadi lebih tinggi, holistik, dan kepribadiannya terbentuk sehingga mudah membedakan antara objek perburuan dunia yang bersifat instrumental dan fundamental. Antara yang palsu dan sejati, antara kebahagiaan sesaat dan abadi, antara halal dan haram"55, dengan ketaatan peribadatan yang kuat dan intensif dari seseorang disebut 'Abid/'Abidun, sehingga seseorang yang 'Abid akan berkata-

52 QS Al Qalam : 4 : Sungguh,engkau (Muhammad) mempunyai akhlak yang agung “.

${ }^{53}$ QS Al Ahzab :21: "Sesungguhnya telah ada pada (diri) Rasulullah itu suri teladan yang baik (uswatun hasanah) bagi orang yang mengharapkan rahmat Allah SWT dan (kedatangan) hari kiamat dan Dia banyak menyebut Allah"

${ }^{54}$ Bambang S Ma'rif, "Psikologi Komunikasi Dakwah Suatu Pengantar "Simbiosa Rekatama Media,Bandung, 2015, h. 152.

55 Komaruddin Hidayat, "Psikologi Ibadah Menyibak arti menjadi hamba dan mitra Allah di bumi “, PT Serambi Ilmu Semesta,Jakarta, 2008, h.115. 
kata yang berbobot disebabkan mendapatkan Shibghah ${ }^{56}$ (celupan) dari Allah, yaitu iman kepada Allah yang tidak disertai dengan kemusyrikan ${ }^{57}$, pembicara yang baik adalah orang yang dalam bimbingan Allah, adalah pembicara yang lahir dan batinnya tercelup dengan celupan Allah, sehingga akan mewarnai akal, hati dan emosi manusia, dampaknya adalah pikiran dan perasaan serta perkataannya yang terbaik dalam bimbingan Allah swt.

Syekh Mustafa Al Maraghi menjelaskan shibghah Allah: "Allah telah mencelup kita dan telah memfitrahkan kita (menciptakan kita pada awal kejadian), sebagai persiapan kita untuk menerima kebenaran dan mengimani segala apa yang dibawa para Nabi dan Rasul-rasul. Maka janganlah kita mengikuti pendapat sesat pemimpin, hawa nafsu tokoh-tokoh masyarakat dan taqlied (taat buta) kepada peraturan buatan manusia. Shibghah Allah adalah perhiasan indah bagi kita yang dengannya kita larut kepadaNya, seperti larutnya warna celupan." 58

\section{Simpulan}

"Qaulan Syakila" dimaknai sebagai perkataan yang berbobot, yaitu perkataan yang memiliki etika dan estetika sekaligus mampu memberikan jalan keluar dari problematik kehidupan, dan hal

56 Menurut bahasa, kata shibghah diambil dari kata shabagha yang artinya mewarnai, mencelup, mengecat, membaptis (dalam agama kristen) dan menenggelamkan, sedang shibghah artinya macam, bentuk, agama, ajaran, kepercayaan dan baptis ( Kamus al Munawwir, h.176)

57 QS Al Baqarah 137-138: "Maka jika mereka beriman kepada apa yang kamu telah beriman kepadanya, sungguh mereka telah mendapat petunjuk; dan jika mereka berpaling, Sesungguhnya mereka berada dalam permusuhan (dengan kamu). Maka Allah akan memelihara kamu dari mereka. dan Dia-lah yang Maha mendengar lagi Maha mengetahui. Shibghah Allah, dan siapakah yang lebih baik shibghahnya dari pada Allah? dan hanya kepada-Nya-lah Kami menyembah.

58 Ahmad Musthafa Al-Maraghi, “ Tafsir Al Maraghi”, Maktabah Wa Mathba'ah Musthafa Albabi Al Halaaby wa Auladuhu, Mesir, 1365H/1946 M, Juz 1, h.217. 
tersebut hanya mampu dilakukan oleh orang yang memiliki jiwa/emosi yang penuh dalam ketenangan (nafsu muthmainnah) dikarenakan sistem neurolognya baik, dan hal tersebut hanya akan didapatkan oleh orang-orang yang secara intensif dan kontinyu beribadah kepada Allah SWT ('Abidun) sehingga orang tersebut mendapatkan shibghah Allah (celupan dari Allah SW), yang dengan celupan dari Allah SWT itulah seseorang 'Abidun (manusia pengabdi kepada Allah) akan mampu melahirkan perkataan yang berbobot (Qaulan Syakila).

\section{Daftar Pustaka}

Ahmad Musthafa Al-Maraghi, “ Tafsir Al Maraghi”, Maktabah Wa Mathba'ah Musthafa Albabi Al Halaaby wa Auladuhu, Mesir, 1365H/ 1946 M, Juz 1

Al Ustadz Adam Cholil, Dahsyatnya Al Qur'an, Al Qur'anul Karim menjadi petunjuk dan solusi Bagi Umat Manusia dalam mengarungi Samudera kehidupan, AMP Pres, Jakarta, 2014

Abdul Mujib,et.al, Nuansa-nuansa Psikologi Islam, PT.RajaGrafindo Persada,Jakarta,2002.

Achmad Mubarok, Psikologi Dakwah Membangun Cara Berpikir dan Merasa, Madani, Malang, 2014.

Annie Sailendra berjudul " Neuro Linguistic Programming (NLP) dari konsep hingga teknik, Solusi Distribusi, Yogyakarta, 2014.

Bambang S Ma'rif, "Psikologi Komunikasi Dakwah Suatu Pengantar " Simbiosa Rekatama Media,Bandung, 2015.

Dori Wuwur Henddrikus, Seni Berbicara, Ledalero, Maumere, 2014.

Henry Guntur Tarigan, Berbicara Sebagai Suatu Ketrampilan Berbahasa, Angkasa, Bandung,t,1993.

Imam Al Ghazali, Ringkasan Ihya 'Ulumudin, Penyuting Abu Fajar Al Qalami, Gitamedia Press, Surabaya, 2003.

Jalaluddin Rakhmat, Islam Aktual, Refleksi Seorang Cendikiawan Muslim, Mizan, Bandung, 1991.

-------, Psikologi Komunikasi, Remadja Karya, Bandung, 1989.

Komaruddin Hidayat, "Psikologi Ibadah Menyibak arti menjadi hamba dan mitra Allah di bumi ", PT Serambi Ilmu Semesta,Jakarta, 2008.

Ki Moenadi MS, Pengembangan Daya Bakat Kemampuan Manusia, Tanpa Penerbit, T.Th, 
Muhammad Alfan berjudul : "Pengantar Filsafat Nilai", Pustaka Setia, Bandung, 2013

Nina Winangsih Syam, Komunikasi Peradaban, PT Remadja Rosdakarya, Bandung, 2014.

M.Najmi Fathoni " Strategi Komunikasi Model Sang Nabi, mengupas kecerdasan komunikasi Nabi Muhammad saw", PT Elex Media Komputindo, Jakarta, 2018.

Sukanto, Nafsiologi Refleksi Analisis Tentang Diri dan Tingkah Laku Manusia, Risalah Gusti,1995.

Tata Taufik,HM, Etika Komunikasi Islam,Pustaka Setia, Bandung, $2012 .$.

Ujang Saefullah, Kapita Selekta Komunikasi Pendekatan Budaya dan Agama, Simbiosa Rekatama Media, Bandung, 2013.

Wahyu Wibowo dalam bukunya yang berjudul : Konsep Tindak Tutur Komunikasi, Bumi Aksara, Jakarta, 2016.

Zulkifli Musabba, Terampil Berbicara Teori dan Pedoman Penerapannya, CV Aswaja Pressindo, Yogyakarta. 2012. 